\title{
EMPOWERING PUBLIC SPACES AS CATALYSERS OF SOCIAL INTERACTIONS IN URBAN COMMUNITIES
}

\author{
Gintaras Stauskis ${ }^{1}$, Frank Eckardt ${ }^{2}$ \\ ${ }^{1}$ Vilnius Gediminas Technical University, Department of Urban Design, \\ Pylimo g. 26/ Trakug. 1, 01332 Vilnius, Lithuania \\ ${ }^{2}$ Bauhaus-Universität Weimar, Institute for European Urban Studies, \\ Bellvederer Alle 5, DE-99421 Weimar, Germany \\ E-mails: ${ }^{1}$ Gintaras.stauskis@vgtu.lt; ${ }^{2}$ Frank.Eckardt@uni-weimar.de
}

Submitted 21032011

\begin{abstract}
Improving public spaces is a strategy of great importance for the successful future of our cities and their communities. The potential of places for citizen communication is often underestimated as stimulus for growth and development of urban communities and therefore public spaces are underused. The article analyses socioeconomic and psychological effects of architectural arrangement of traditional public spaces in modern perspective as areas for social interaction between different neighbourhood and citizen groups in an urban community, based on case examples of two cities: Vilnius in Lithuania and Weimar in Germany. Analysis of changing spatial composition and principles of social functioning are directly dependent on socio-political system of each different historical period and represent the chronological evolution of the present architectural appearance of the presented urban squares. The importance of local urban territorial communities is underlined in the article as they are the most important social entities for identifying the needs of local residents and in many cases are ready to take over the responsibility for re-arrangement of the public spaces adjacent to their areas of residence. Based on a careful observation of public activities on going in the analysed urban squares in Vilnius and in Weimar, the principles of planning, functionality and spatial arrangement are analysed in the aspect of facilitation of social interactions on going or potentially possible in these spaces. The research identifies planning and spatial arrangement models that could facilitate the preferred ways of social interactions and generate the better overall aesthetical and functional quality of those places.
\end{abstract}

Keywords: urban design, landscape architecture, public space, social interaction, sustainable mobility, accessibility.

\section{Introduction to the problem and recent} approaches to the topic

An uncoordinated sprawl of urban areas into suburban green fields, expansion of development into natural and cultural landscapes and into urban public spaces, and unsustainable mobility systems are identified as the most important recent problems in development of modern cities. The public is abandoning areas of former public use for many different reasons, whereas wrong planning and design of these and close-lying areas play the main role. Aggressive urbanisation is constantly expanding into these centrally located and well-developed are as for development of commercial and residential buildings and new transport elements.
In many ways, this process was tolerated by low quality short-handed municipal management policies, probably driven by the rule "no space - no problem".

Numerous researches that analyse problems of development of public spaces, underline the complex significance of socioeconomic, environmental and artistic factors as the most important aspects for ensuring quality use of these areas. Internationally acknowledged authors have extensively analysed sociological (Eckardt 2010; Fainstein 2010) and socio-psychological (Bell 2008: 373-384) aspects of public spaces underlining the importance of personal and communal safety 
and comfort. Aesthetical quality of a public space in a valuable historical environment attracts more people by ensuring high quality architecture that provides the basis for enjoyment of a visit (Sitte 1896).The aspects of assessing planning and maintenance of public spaces are closely connected to the political-economic system where transformations of a different scale and inclusions of new monumental elements into the existing spatial compositions become possible (Grunskis 2009). Aspects of participatory involvement of local citizens in protecting, modifying and using local public spaces are especially important in the context of approaching radical structural transformations (Hackney 1990). Each public space represents a certain socio-political order of a particular society that it is serving for and becomes a spatial reflection of the latter (Sucker 2010). A thorough analysis can discloses ocioeconomic reasons for specific planning and spatial arrangement of such spaces. Impact of the dominant social order on visual identity of public spaces becomes apparent during different periods of re-arrangement, e.g. the recent ideas competition for transformation of Lukiškių Square in Vilnius (Vyšniūnas 2008). Attractiveness of a public space depends on diversity of accessible services and interests of citizens, where elements of social infrastructure play the key role in empowering contemporary public spaces to act as facilitators of different social activities (Stauskis 2010, 2005). The authors of this article have been researching the topics of accessibility, mobility, health and the related services for communities (Eckardt 2006; Stauskis 2005; Methodology... 2009), underlining the importance of well-planned and accessible social infrastructure as the element that attracts residents to urban public areas. In the presented research, the authors give a comprehensive analytic outlook on modern public spaces, also providing the concept planning principles based on examples of the analysed historical public spaces situated in the old towns of Vilnius and Weimar.

Attention has been called for by various authors (Gehl 1996; Feldtkeller 1995) researching public spaces that indicate the intrinsic meaning of the built environment for enabling the constitution of social meaning. In this regard, some of the questions have still not been solved consequently to that extent, that architectural and planning practice could be related to its potential social functions (Klamt 2011). A complex understanding of the significance of public spaces is thus presented on the following pages aiming to revisit the possibilities of interpretation of public spaces for the requirements of design.

\section{Historical aspect in identification of public spaces in urban areas}

During different periods of historic development of an urban tissue, the built-up areas as urban blocks were interchanging with open spaces that were mostly used for different types of social interaction, which corresponded to the type of socio-political and economic system of a particular time period (Sucker 2010). How and when certain public areas were used is determined by the ways citizens interact or as promoted by authorities. As political-economic systems were changing in evolutionary or revolutionary ways, so - ether smoothly or dramatically - was the social life on the very same public spaces. The diverse changes ranged from periods of neglect and complete abandonment to redevelopment for housing, commerce or other practical functions, and assignment for various infrastructural needs such as streets, crossings, parking lots or urban landscapes and recreation facilities. Another possible reaction was the rediscovery of importance of these areas and change of their functional and spatial identity towards the recent social tradition to be re-used by citizens living under conditions of the recent socioeconomic system. As a result of redevelopment, the former open spaces were built-up and started gradually disappearing from the system of open spaces as well as fading from social memory. The second trend of re-using such spaces according to the new socio-economic conditions is more complicated, however, numerous examples can be found in Vilnius and Weimar as well as other European cities to illustrate this tendency. Lukiškių Square in central Vilnius might serve as a good example of the underlying complexity of transformation. Planned in the form of a recent shape in the 18-19 c.c. as a front area of the Governor's Court, where time to time the court sentences and even public executions took place, later, for a half of a century, it served as an ideological memorial place of the occupying Soviet regime with dominating figures in the central point of this geometrically planned square. Since the overthrow of the occupying regime and restoration of independence in 1990, Lithuanian national and municipal authorities have been struggling with re-arrangement of the square to erase the negative ideological imprints and accommodate the centrally located space for modern use by residents of Vilnius. Numerous architectural competitions with the greatest variety of planning, design and landscaping proposals reflect the whole complexity of the task, in which the absence of a proper social programme is the basic reason for so lengthy delays and confusions in architectural proposals. 
Of similar significance is the Theaterplatz in central Weimar, Germany. Mainly, the statue of the two poets Johann Wolfgang von Goethe and Friedrich Schiller holding each other has found the nationwide recognition. Weimar is a small city with a big name, which is recognized by both local inhabitants and external visitors as the city's legacy is linked to the work and life of these two writers. The photo of the statue on the Theaterplatz is reprinted by numerous publications referring to Germany in general and often without even mentioning Weimar (Fig. 1). The most famous Baedecker travel guide for Germany has been using this picture as the cover image until recently.

Today, the statue on the Theaterplatz is the most photographed object and the main attraction for tourist visiting Weimar. Although probably unappreciated by many visitors of the contemporary Weimar as something that represents the "better Germany", this is exactly what the statute embodied for a long time (Fig. 2). This perception is based on a myth (Eckardt 2006b),

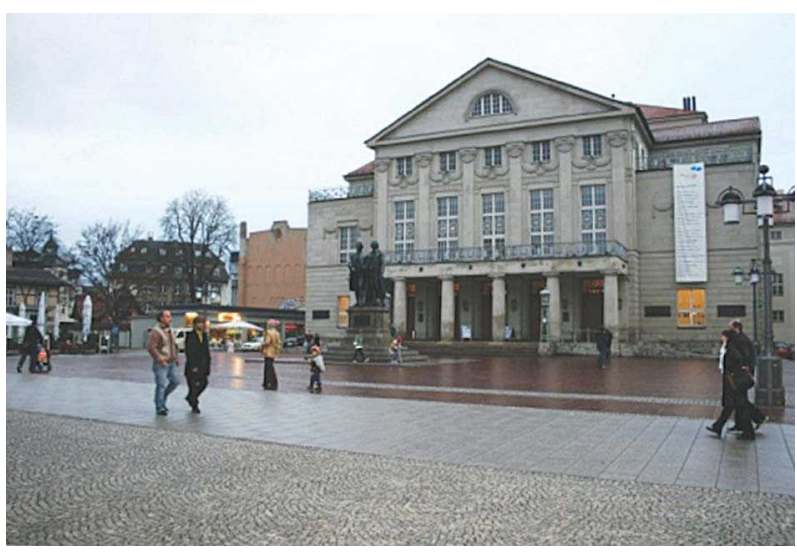

Fig. 1. Theaterplatz - the most vivid public space of Weimar and main destination for tourists. Anika Müller fig. Mar. 2011

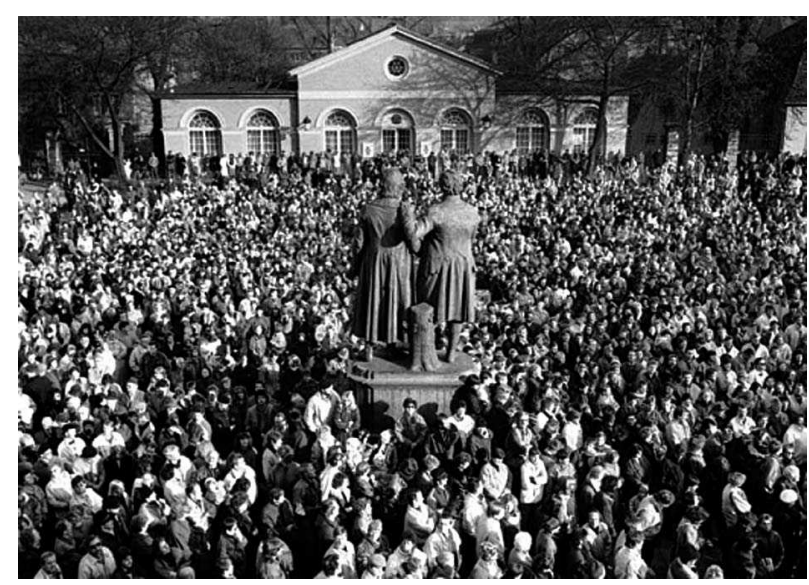

Fig. 2. Theaterplatz in Weimar was always a place of the most serious assemblies for local citizens. Citizens' meeting on the occasion of reunification of Germany. Nov. 19, 1989 which originated at the time when both writers resided in Weimar and the city became the place for intellectual pilgrims seeking for some kind of an enlightened movement, which, apparently, was expressed in the form of the French Revolution in France, however was violently repressed by the fragmented and restorative German states. Schiller fled from political persecution to Weimar from the South-West of Germany and Goethe - apart from his literary production - got involved in the local court to introduce modern reforms.

However, the reality was more complex and the myth of a "place of German enlightenment and democracy" left out the fact that Weimar was not as democratic as the retro-perspective claims had argued. When the first democratic parliament had to flee for a short while because of the violence in Berlin after World War I, Weimar seemed to be the natural and undoubted choice to refer to some democratic tradition. In his announcement of the "Weimar Republic" on the Theaterplatz, the first German democratic President Friedrich Ebert used this myth as legitimation. But very shortly afterwards, the members of the parliament learnt they were unwelcome in this city as they were not served in local restaurants. Later, hostility against the democracy and modern life has also led to expulsion of the Bauhaus Movement and to the more than warm welcome of the Nazis. Weimar was visited by Hitler 19 times and was declared to be his favourite city. The concentration camp on the hills of Weimar (Buchenwald) had been explicitly planed by him to "clean" the city from the last remaining democrats. The city refused admitting to its involvement in these crimes up until 1999 . Today, there is nearly no reference to the "Weimar Republic" on the Theaterplatz. During the socialist period, Weimar and the Theaterplatz were mainly used for ideological events to support the ruling party. Paradoxically, praising this place as pre-socialist monument for freedom, the authorities did never allow any kind of freedom of opinion and expression. Even a few days before the end of the regime, graffiti spraying youth were violently persecuted and imprisoned without a trial. Throughout different historical periods of Weimar development, from the XIXth c. to the recent days, the planning and spatial arrangement of Theaterplatz has maintained its historic shape. Still, the socio-political attribution is identified by changes in the basic elements of this public space as pavements and the green floor, street furniture and light as well as the visual design (Figs 3-6). In spite of functional, stylistic and spatial differences, the comparison of social functionality of selected squares in Vilnius and in Weimar reveals many common traits to be named in the following step of the analysis. 


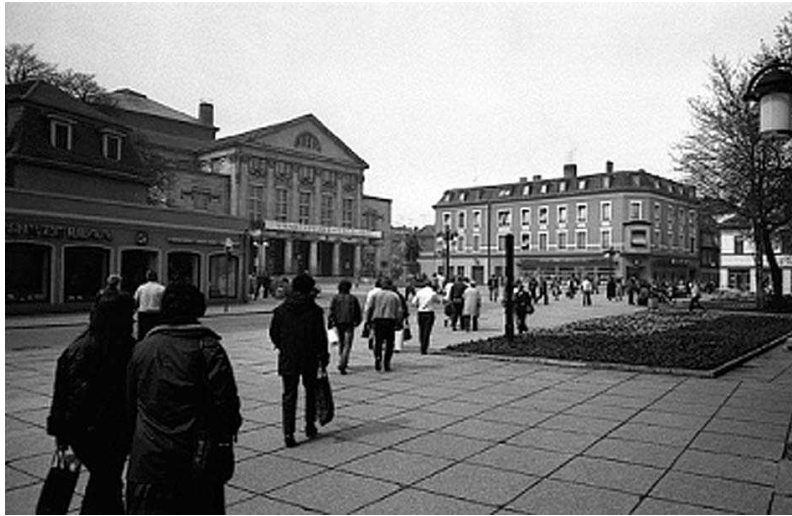

Fig. 3. The Theaterplatz is located on an urban crossroad, it was always actively used by pedestrians. 1980

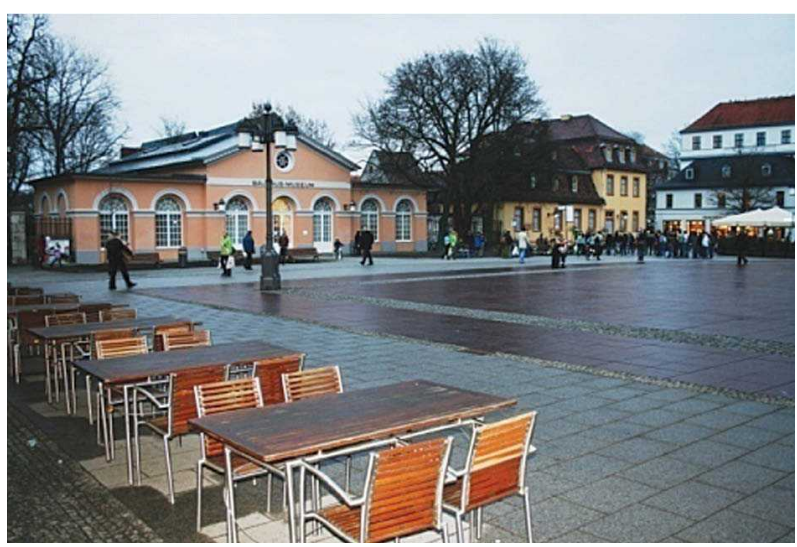

Fig. 5. The old Bauhaus-Museum at the Theaterplatz. Anika Müller fig. Mar. 2011

\section{Social interaction in analysed public spaces}

While analysing types of resident interaction in open public areas, one should clearly see the wide range of users and user interests, also - the different patterns of functionality. If to start reflecting on the territorial hierarchy of public spaces from the smallest area, a courtyard of a private house would be the smallest space that is certainly much more private than public. In fact, a neighbourhood is the smallest social unit interested in an area for all types of interaction; and this mission is carried out by a space of an urban neighbourhood. A local territorial community is a higher and bigger urban social entity that identifies areas of its primary (e.g. residence) and the secondary (e.g. recreation) interest and needs a space for all types of its intercommunicative activities. The third level in this hierarchy is a space for the entire city where all residents could meet in spite of the particular place of residence. Some of the most important public spaces usually located in capital cities are

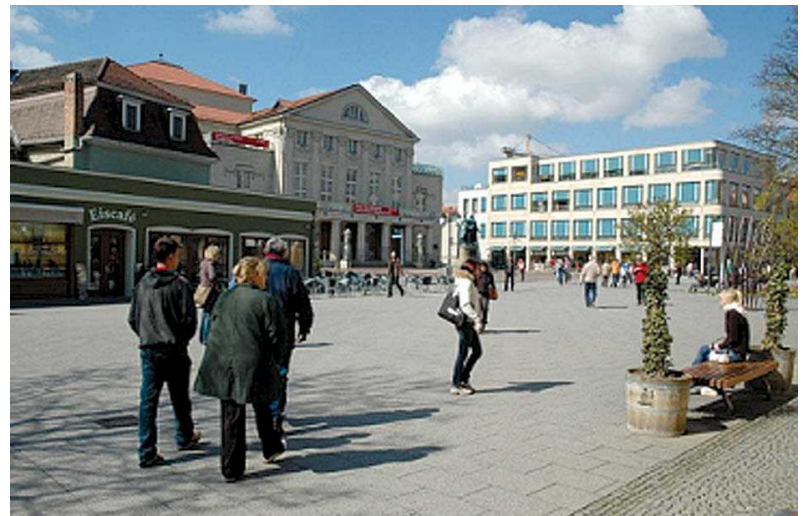

Fig. 4. Recently, more space for public show on the Theaterplatz and some place for the spectators appeared. 2011

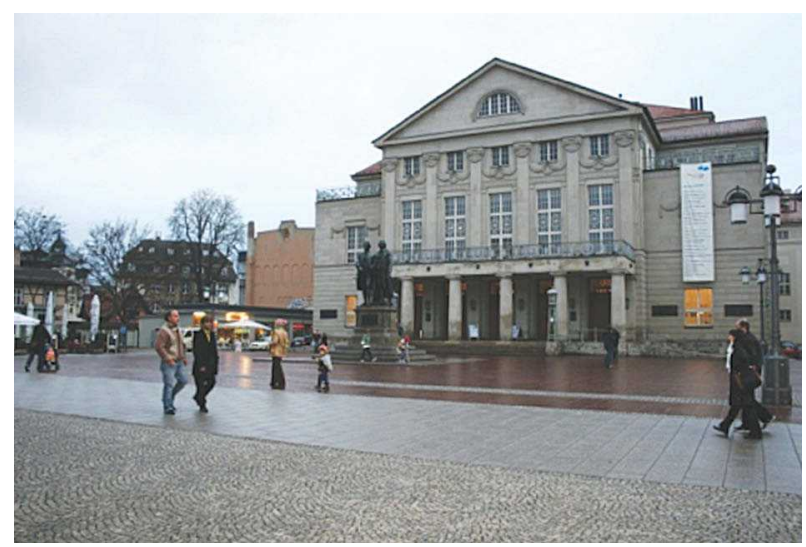

Fig. 6. Theaterplatz - the most vivid public space of Weimar and main destination for tourists. Anika Müller fig. Mar. 2011

not only significant to that single city but also to the identity of a region (i.e. regional centres) or an entire country.

The presented typology is closely connected to the system of urban residential areas. Indeed, housing is extremely important for the live lines of public spaces. However, attractive and functional spaces could be established next to commercial centres and shopping malls (a number of examples of such attempts can be found in Vilnius), local administrative units or municipalities, or any kind of public facilities, e.g. a school, a sports or a health centre. Still, the absence of a stabile local community prevents the space from becoming a lively and vibrant public area with stabile functioning for all times and seasons. The key to the "Public Space" phenomenon hides in the fact that it is sometimes forgotten that such spaces are supposed to be public, and the word "public" means a neighbourhood, a local community, and citizens of an entire city, an urban region or even a country, as well as visitors. Consequently, there can be no public space without 
the public that is only present in particular residential areas and structures.

Although the general typological hierarchy is structured as provided above, the recent period of development made public spaces more integral. It became somewhat usual to mix different activities of importance to a neighbourhood, a local community, a city and even a nation in the same or almost the same spaces. This provides more possibilities for the use of such spaces and simultaneously generates more interest and social attraction of the wider public.

As for sociological missions, a public space is an arena where different social groups carry out a range of very specific social activities that are noticeable for a sharp-eyed viewer. Community groups publicly present themselves to their community by preparing and showing various specific acts that could be called "social performances" for locals and the passing-by visitors; they get feed-back from groups of observers - "the spectators" - among which there are always groups of sceptics, critics and enthusiasts. Some types of activities are welcome (silence also means approval),whereas the public seems indifferent and generates no reaction in case of others, and some are met with clear opposition and condemn. In order to continue a performance ("show must go on"), one social group (e.g. teenagers) has to come to a consensus or a sort of a silent agreement with other groups (e.g. the elder residents). For example, roller-bladders could be accepted neutrally in a residential area, but some people could complain about them on a busy pedestrian street. By this interactive communication, the models of certain social behaviour that are acceptable for all or a clear majority of participatory groups are generated by representatives of a certain community. The social liveliness or death of a public space could be measured by evaluating the presence and intensity of these social interactions and generation of its result in a form of certain publicly accepted behaviour models.

These models differ by country and region, based on geographical, ethnical and cultural specifics; they could also differ depending on a place in the same city. Probably a vital role in determining those models and traditions of social behaviour lies in specifics of an existing community, which is shaped a lot by the nature and urban environment of its residence. So, the mutual inter-dependence in this case is evident: people shape the environment as to their needs and the environment shapes the way people behave and express their needs and desires. The unexpected paradox is that the very same models of social interaction and public behaviour could be acceptable in one community and absolutely rejected in another, even in the same town.
For example, smoking or drinking in public might be acceptable in some places, but completely opposed to in others, e.g. sacral spaces. It is important to note that these models cannot be imposed "from top down" by laws and regulations. They should come from a community, thus a wise law would simply follow these unspoken social conventions that developed over years of social interaction in traditional communities. Now, the issue of protection of traditional historic environments clearly stands out: traditional environments should be saved and preserved as places of residence of traditional communities, which develop models of social behaviour and interaction that actually belong to the sphere of city culture. Ruination of historic legacy breaks social contacts in local communities that soon fall apart together with local traditions and culture. Some architects build their professional career on consulting authorities about local communities and have a great merit for preserving and renovating many traditional places instead of pulling them down (Hackney 1990). It is also well known that it takes a long time before new social traditions are born and bred in newly built areas.

In this context, the most important principle to be observed by professionals of architecture is that the physical form of any taken public space of how it is planned, built-up, paved, painted or arranged landscape-wise is just an external shell, in which an architect that understands the basic codes of typical social interactions "dresses" the space by giving it an appropriate architectural expression in space and form. There are numerous cases when architects are unaware of these basics or being driven solely by formal stylistic fashions and trends create fancy glittering but socially dead spaces. An urban community of a different scale can easily do this modelling and "dress" itself, maybe in a less fancy but much more efficient way. In all cases, the public is testing, evaluating and deciding on acceptance or rejection of the space as a social arena for their public communication.

The above described public interaction models are vital for any society and especially for that of urban citizens. They keep people and their communities together, facilitate their rise and strive towards common goals; they also educate young generations and handover the cultural legacy of their urban neighbourhood. On the other hand, absence of these common goals and interruption in transfer of inherited cultures is observed in many places of the analysed cities. The reason possibly hides in the lack of common behaviour models developed in these communities, probably because of insufficiency of adequate public interaction stages for those activities to happen. 


\section{Planning the specific elements of public space for facilitating social interactions}

Differences in age, culture, profession, hobby and etc. consolidates different groups of interests in a community that need to showcase or express their character and hear the feedback from their neighbours. Preparation for the public show takes place differently but usually in a little place, hidden from the eyes of the public (see Fig. 7). E.g., a place for cycle parking stands is needed both by the actors and by the spectators. It could be named $\boldsymbol{a}$ back-stage and located next to the main performance and interaction area -the front-sta$g e$ that should be located in a focus area of the space, clearly visible from all corners from the point of view of a spectator. It should receive plenty of sunlight and be undisturbed by the flow of passers-by. Proximity of any dominating elements of art, such as sculptures, statues, columns, installations, etc. is good for the stage. Sizes of these sub-spaces (nominal spaces) depend on the number of participants and the intensity of the ongoing shows. For the bigger and more important public spaces, such as central squares or the main malls, preparation and performance areas should be bigger and there could be even few of areas planned for simultaneous shows. The types of activities or "performances" are most diverse and could range from quiet (standing, sitting, lying, leaning) to medium (dialogue while walking, speaking, listening) and active (all types of physical exercise, skating, cycling, skateboarding, jumping, singing and dancing). The type of performance is selected by the "actors" according to the functionality and suitability of the place.

The next necessary element needed for a lively public interaction is spectators of performances and a proper space to host them, i.e. the spectators' area. It should be big enough but not too vast so people would still feel cosy together; it should be well located: pro-

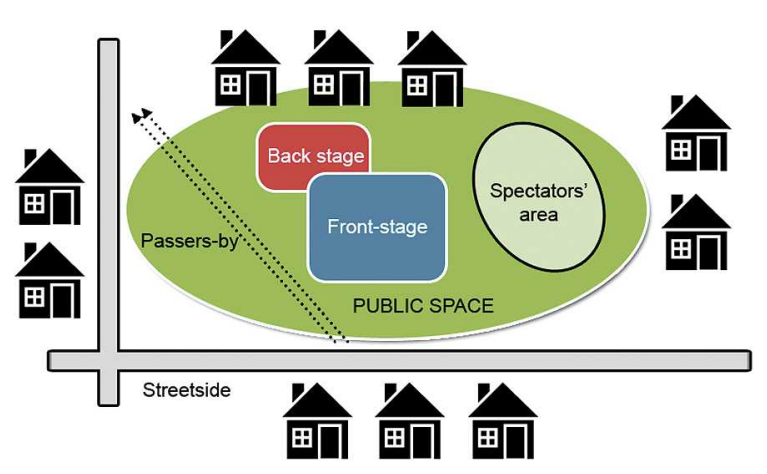

Fig. 7. Schematic structure of users activity areas on a public square to facilitate public interactions tected from direct sun rays, excessive urban noise, rain or cross-wind, and microclimatic conditions should be considered. Proper arrangement of the spectators' area is vital for the show to start and continue. The main idea for planning of such spaces could be expressed by the phrase "no spectators -no show". This area could be well adjusted to different irregularities of a site but still have a good eye-grip on a front-stage. Spectators should be given an opportunity to stop, stay and watch the performance that is ongoing on the stage. Therefore, presence of some functional street furniture is important for sitting or at least leaning on.

Almost all urban open spaces have a flow of passersby. They are cutting a corner across a square or park and have little interest in an event that is happening there at least on the given moment. To ensure a smooth continuation of main activities, the passers-by area should be gently sheltered away and allocated a more remote yet still functional route away from the stage and especially from the spectators' area. Flows of strangers across the intimate centre of the show should be avoided to give more tranquillity to intercommunication of people in the area. Still, some of those passers-by could once turn into more interested spectators especially if they continue finding themselves in the midst of repeated ongoing attractive social performances. The transit flow of pedestrians and cyclists should be planned in a functionally assigned line away from quiet areas but still ensure good accessibility of the space (see Fig. 7).

One could reasonably touch upon the aspect of safety, which is also vital for any activity in a public space where some areas (nominal spaces) could seem dangerous and unsafe for people. Usually, such are places abandoned by other users, dark or shaded, or littered and hidden from spectators. If such area is arranged in the above-described manner, it would soon become popular. This is the soft and sustainable way of adding to the safety of a public space. The additional hard measures (e.g. surveillance cameras, fences, gates, locks) could be also applied but more as additional means because building the public safety just on hard measures alone would not bring a sustainable result but rather highcosts and temptation to violate the imposed order.

Architectural tools used to model the spaces for above-mentioned social interactions in public spaces are very diverse; their particular applications depend on the location, size, terrain, microclimate, landscape and other potentials of a place. Variety and combination of hard (buildings and their structures) and soft (elements of landscape: relief, plantings, pavements) measures in combination with universal design elements (microclimate, light, colours, materials, textures, etc.) allow for proper arrangement or re-arrange- 
ment of various different spaces to facilitate the most involving social activities.

The show has the time it starts and ends; it has breaks, both for artists and spectators. Additional services, such as food and drinks on the spot, can prolong the show as well as more comfortable seating arrangements to watch the ongoing activities. The longer is the show, the deeper is social interaction. A greater number of different shows can generate a more intensive communication and more comprehensive behavioural conventions in a shorter time period.

Strangely enough, one can see many parallels between the depicted activities in public spaces and a show performance in a traditional theatre from where some vocabulary was borrowed for the sake of a more vivid depiction.

\section{Spatial concepts for empowering public spaces - examples of Case Studies in Vilnius and Weimar}

Theoretical principles presented above were collected and structured by observing and analysing resident activities in public spaces of Vilnius and Weimar cities. The scope and location were selected in historic city centres by choosing traditionally meaningful and popular places with memorial artefacts: squares informally named Moniuškos, Pranciškonų and Arklių in Vilnius and the Theaterplatz (Theatre Square) in Weimar. Selection of the sites reflects the focus of analysis on the historically dominant points that bare traits of many periods of urban development in Vilnius and Weimar as well as are very important for the recent urban life on a local and wider scale.

All of the selected spaces in Vilnius are situated on the cross-road of the most important historical tracks and pedestrian walks of the Old Town, leading from the Town Hall Square to the main suburban directions via historical gateways. They all bare traits of several historical periods; and have gone through more or less radical structural, functional and aesthetical transformations yet preserved their original features. They all have experienced the renovation invasions planned by architects and encouraged by city authorities. And all of them are still popular at least for being located in the heart of the Old Town, yet have certain problems with attractiveness, functionality and public use. All of these reasons make them worthy of a more careful attention of a researcher and, therefore, they were selected as case studies amongst many other public places in Vilnius city.

Next to the historically famous Vilnius Street, leading from the Town Hall Square to the northern su- burbs via the Green Bridge, lies the Moniuškos Square, which stretches beside the St. Catherine's Monastery and Church (Fig. 8).It was planned and developed as an internal courtyard of the convent with the lovely facade of the church as one of its spatial formants (Fig. 9). For centuries, its internal space was sheltered from the street by a solid, high wall and a small building of an unidentified function, probably a chapel or a campanile, which existed there until the end of the XIXth century. As city streets were widened in the middle of the XIXth c., the internal square was stripped of its solid walls for the gentle and low cast-iron fence, which was moderately separating the square from the street. More space of the former convent was added to the public square, where a relatively small scale memorial statue to Stanislaw Moniuszko (1819-1872) was installed in 1932. The most recent renovation of the square imposed a very formal central axis leading strait to the main entrance of the church and merged the internal space of the square with busy lines of Vilnius Street sidewalks.

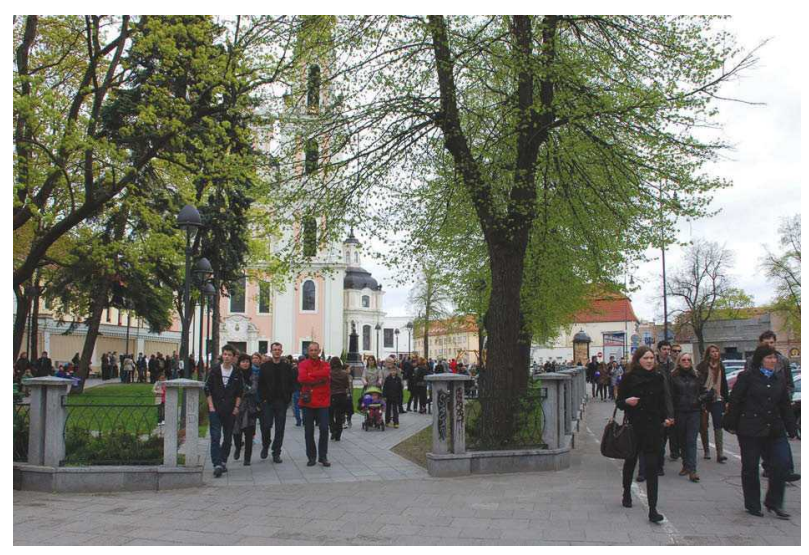

Fig. 8. Traditional way along the street side walk suddenly turns into the quiet ambience of the Moniuškos Square. G. Stauskisfig. Mar. 2010

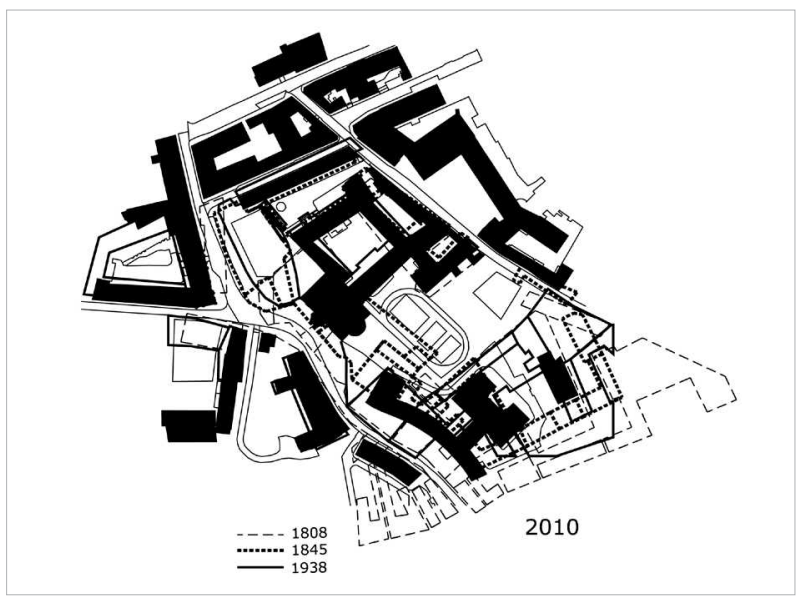

Fig. 9. Planning evolution of Moniuškos Square in Vilnius XIX-XXI c.C. 
Now, much more than before the intensive transit flow of passers-by interferes with the quiet recreational oasis of the square, which evidently disturbs any happenings (e.g. social performances and their observation) on the square. There is a proper stage (front and back) and different spectator areas, thus younger "artists" enjoy the very central seats as well as the more recessed ones (Fig. 10).

Beside the next urban gateway leading from the heart of the Old Town to Trakai - the ancient capital of Lithuania - on Trakai street, lies the square of the Franciscan Convent (Fig. 11). Again, having appeared as an internal courtyard of the Franciscan Convent and adjacent to the Franciscan Church, the square served many functions, including the cemetery for noble citizens up until the very end of the XVIIIth c., which was brutally excavated from the square by Soviet authorities in 1968. According to the analysis of historical developments (Fig. 12), the boundaries of the square were changed and a transit flow of pedestrians appeared.

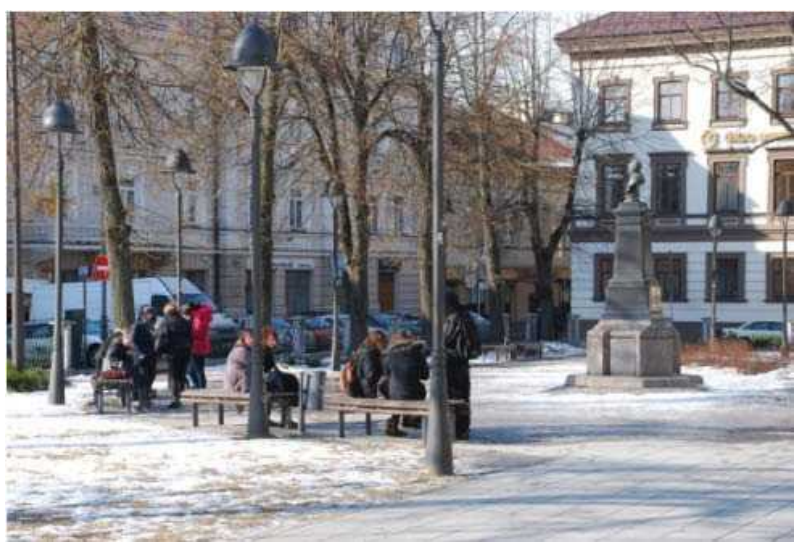

Fig. 10. Spectators prefer to sit aside from the busy transit flows on Moniuškos Square. G. Stauskis fig. Mar. 2011

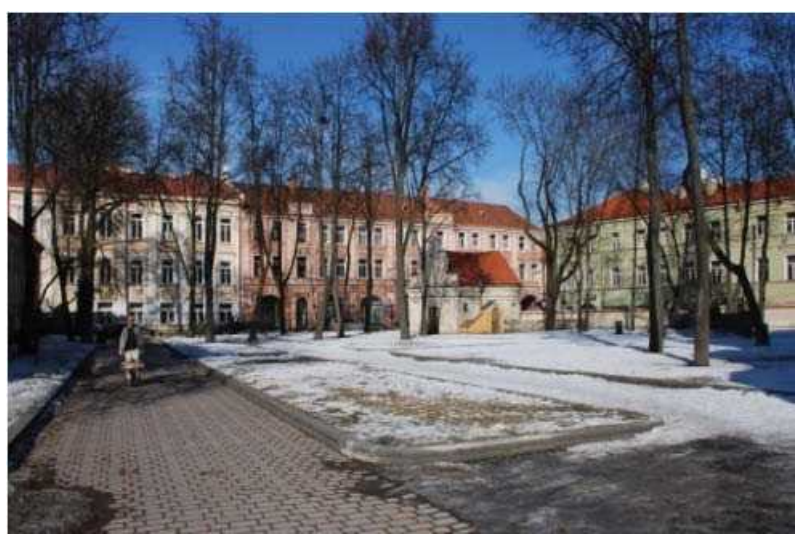

Fig. 11. An extra-wide transit route leads to the side of the Pranciškonu (Franciscan) Square leaving the main space free for the observers and the performers. G. Stauskis fig. Mar. 2011

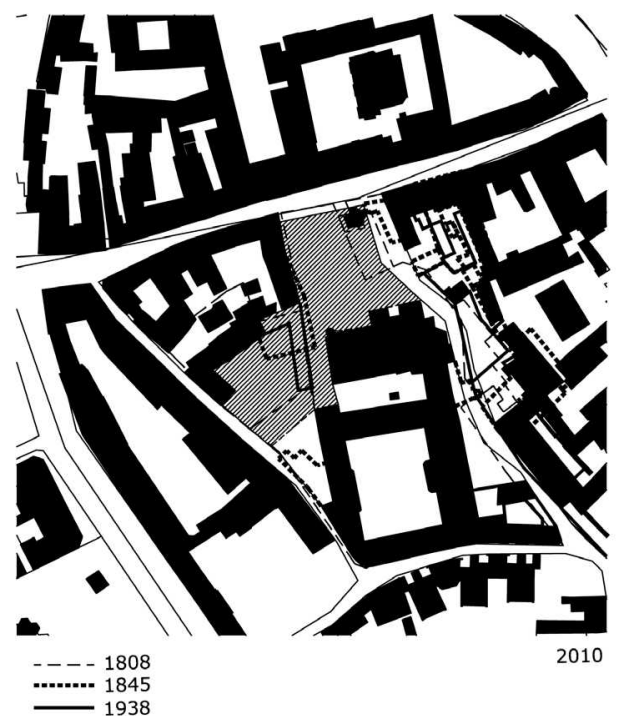

Fig. 12. Planning development of Pranciškonų Square in Vilnius XIX-XXI c.c.

The overall space was changed and increased during these periods mainly by installing a new street during the second half of the XIXth c. and demolishing some buildings after the World War II.A quiet monument to nobleman Juozapas Montvila (1805-1911) was installed in 1935 and the square gained a greater memorial importance (Fig. 13). By placing the transit flow along the bordering facade, the square gained certain function of recreational communication. There is a clear performance area, even a small back-stage and a predesigned sitting space for spectators. Some visitors are always present on the square: kids from the across-thestreet kindergarten, students from local schools and universities, and certainly monks and priests together

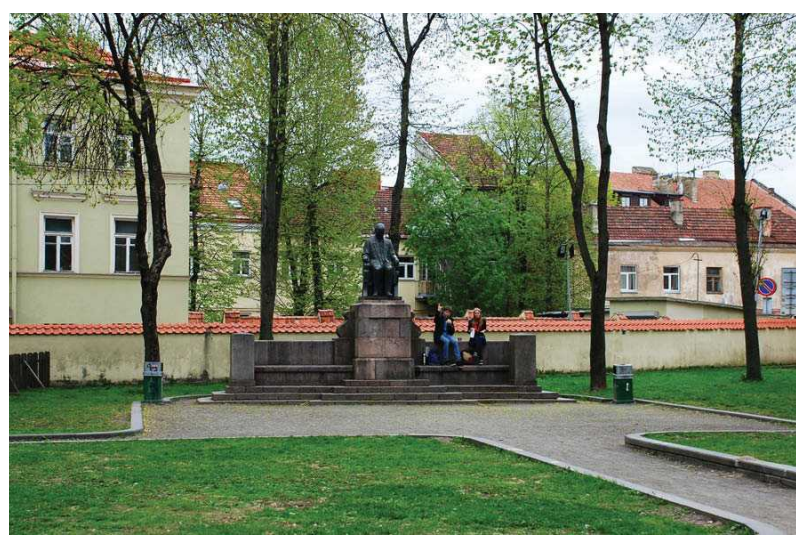

Fig. 13. Spectators make use of ready-made observation seats by J. Montvila monument on the Pranciškony (Franciscan) Square. Even a certain back-stage is fit for user performances behind the monument. G. Stauskis fig. Mar. 2011 
with members of the congregation. The very peculiar mixture of users of the square is especially typical to Vilnius Old Town, where the mix of people of different ages, professions and backgrounds is rather a rule than an exception. The overall planning and zoning of the square is good but some elements, such as pedestrian roads, the green carpet and plants, square furniture and light, have to be transformed and redesigned to bring more usability and comfort for visitors in the process of their interaction.

Arklių Square gained its present shape after the last street widening in Vilnius took place and some former developments that were obstructing this process on the southern side of the block were demolished (Fig. 14-15). The analysis of the historical planning evolution revealed that the recent square space was a former inner courtyard of several possessions, and once some buildings and their fences were demolished and the street leading to the Hale Market was widened, finally - on the second half of the XIXth c. -it turned into a very open space with especially intense cross and diagonal pedestrian flows. A monument to prominent Lithuanian writers (two sisters) of the first half of the XXth c. Lazdynu Peleda was created by Dalia Matulaite on the intersec- tion of the main pedestrian walks in1995. Being located in a very central area of Vilnius Old Town, the entire space of the square is still far from attractive for social interactions for several reasons. As was the case with the previous sites, the space of Arkliu Square is subdivided into many small pieces by pedestrian flows coming from several directions across the centre(Fig. 16-17). Even though the general area of paved surfaces is irrationally large, the quiet places and the green carpet are small and split, and therefore there is no identifiable social interaction. Landscape elements in the form of tall trees and land shape are very scarce, thus form no clear spatial structure in the square. The lines of tall trees were planted along the main streets during the post-war period and the absence of smaller plants creates a void in the internal space on the square. In summary, there is some stage available; however, drastic flows of passers-by prevent appearance of prepared performers and, consequently, the spectators. Several groups of stairs and absence of ramps make the square space inaccessible for many residents including infants, elderly and the disabled.

The case of the Theaterplatz in Weimar reveals a similarly peculiar picture. This space is highly attractive

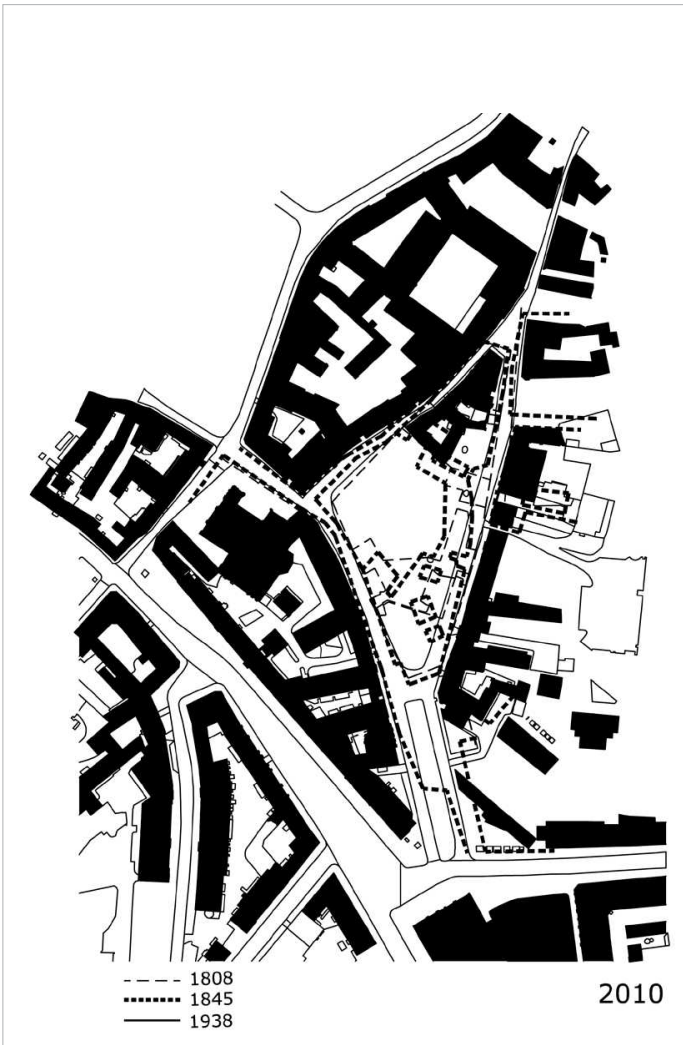

Fig. 14. Periods of planning evolution at Arklių Square in Vilnius XIX-XXI c.C.
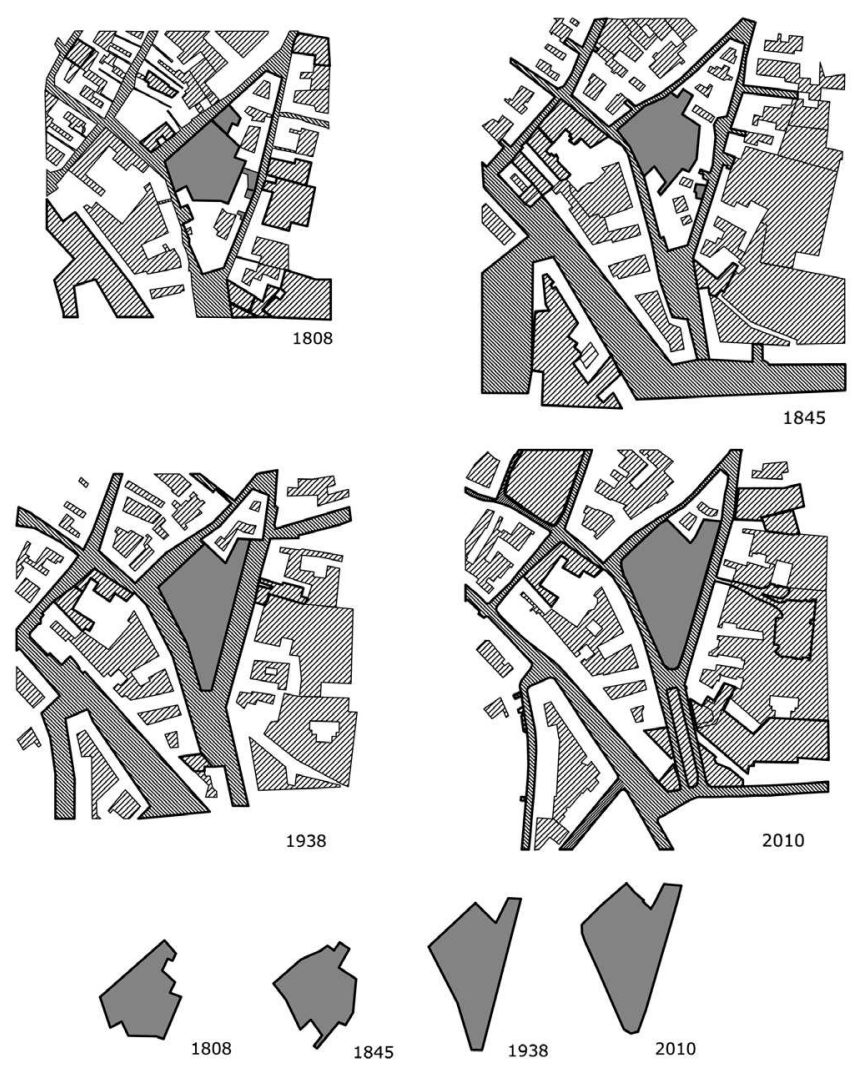

Fig. 15. Changing spatial structure of Arklių Square in Vilnius during different periods of historic development 


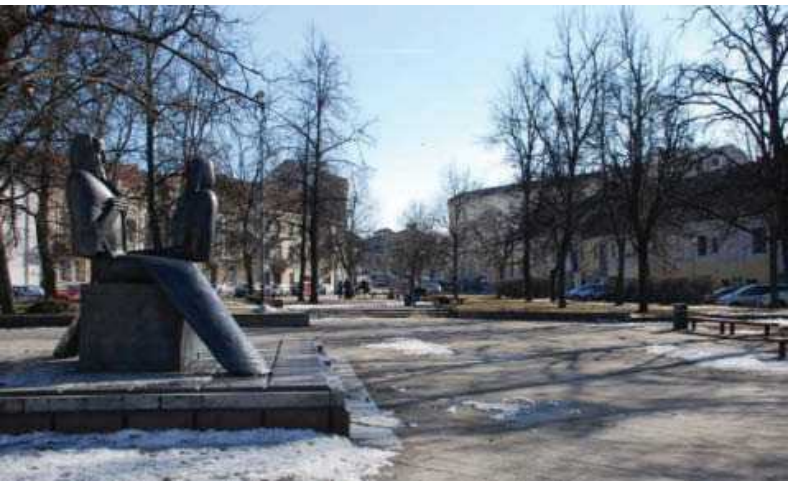

Fig. 16. Through-pass is cutting across the nice scenery of a historic space of Lazdynu Peledos Square where spectators area is split by the transit route and there is no back-stage. G. Stauskis fig. Mar. 2011

for different and diverse activities. It is part of a pedestrian area, which to some extent solves the question of traffic flows, but it still remains to be the place, which requires the entire urban geography to be adjusted to the flow of more than three million visitors every year in a city of sixty thousand inhabitants. Accessibility is thus the main subject for urban planning (see Figs 1-6).

In physical terms, the Theaterplatz can be accessed by foot from seven paths in the old town of Weimar. Two of them are leading further on to other important squares like the Goetheplatz and the Marktplatz. These two are the most relevant for steering of the traffic flows. As most of tourists visit the city for one day, the traffic route is dominated by busses. Two main parking areas were created near the square for buses of day visitors. Both of them are located close to pedestrian streets but feel as if they were outside of the inner city. Parking has however become the main concern for local sand a challenge to urban planning. Since 1999, when Weimar was hosting the European Capital of Culture events, the urban planners and local politicians started giving in to allocation of more squares for tourist attractions. As popular resistance made the use of the nearby Rollplatz for public art exhibitions impossible as it is now used as a parking lot for near-by dwellers, it seems that expectations to have more space for tourism seem unrealistic. Obviously, the inner city of Weimar has severe parking problems and answer has are yet to be found.

The problem of accessibility has led to severe redirections in the use and design of the Theaterplatz. This became obvious in the debate regarding two major projects: the rebuilding of the Bauhaus Museum and the idea of an information centre on the Weimar Republic. It is assumed that both projects would increase the number of visitors to the Theaterplatz and

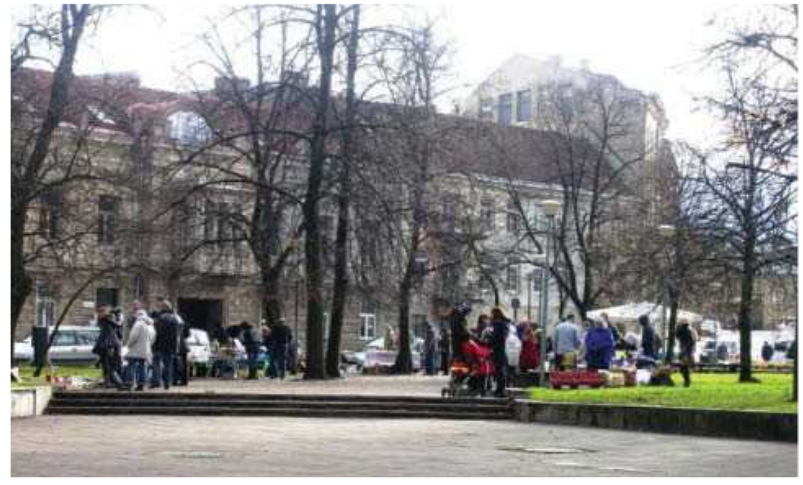

Fig. 17. A weekend flea-market on the Lazdynu Peledos Square is are al show where spectators are more active than actors. I. Urbonaite fig. Oct. 2010

thus the problems of accessibility would amplify. The decision was taken to build the new Bauhaus Museum outside the inner city, next to the bus parking. The development of a sort of "Republic Café" that was favoured by the Bauhaus architect Steffen de Rudder does not begin as it would intervene in the total imaginary composition of the Theaterplatzand might disturb the mystified perspective described above.

The Theaterplatz is onthe vergeof becoming a more museum-like place than would represent a real democratic and free urban life (Eckardt 2011). The process of negotiations between different social groups on use and design of this symbolically overloaded square has begun only recently. Even the most insignificant incidents are used as an excuse to restrict the access of "unwanted" persons that do not fit the Goethe-Schiller image of the Theaterplatz. While the National Theatre managed to come to an agreement with young skaters to not disturb the visitors of the theatre during certain times, tourist guides show no such tolerance to these local kids and demand for constant police measures. Sociologists and architects of the Bauhaus University have been successful in resolving these conflicts as to enable the access of more different social groups of residents to the Theaterplatz and thereby increase its significance for local encounters of different people in order to make the Square into a real urban space once again.

The presented analysis of urban squares in Vilnius and in Weimar reflects on the different periods of historic evolution and the consequent transformation of these places. The specific problems of social functioning allow us drawing some rather general conclusions that could aid the overall improvement of social tolerance, functionality and the aesthetic quality of these spaces for the benefit of local residential communities. 


\section{Conclusions}

Structural and aesthetical transformations that took place during the historical evolution of the analysed spaces are closely dependent on the socio-political system of the time that has been shaping the public communication.

Spatial structure of an urban square in many ways has a strong impact on the intensity and freedom of social interactions on going in these places; whereas professional intervention based on a careful analysis and selection of proper tools and methods could radically improve the situation.

Local urban territorial communities could and should be involved in programming, concept design, project verification, supervision, management and maintenance phases of a life-cycle of a public square, thus ensuring better social acceptance and satisfaction, the general functionality and more rational and safe maintenance.

Specific elements of a public square such as a frontstage and a back-stage, spectator area and transit flows, and the landscape system (Fig. 1) are the main professional instruments that can facilitate stronger and more open social interactions on public squares.

Good and equal access of citizens of different ages and physical abilities to a public space is vital for its live lines and therefore accessibility of these spaces has to be carefully surveyed, evaluated and improved.

\section{References}

Bell, P. A. 2008. Environmental Psychology. Lawrence Erlbaum Associates. London.

Cullen, G. 1990. The Concise Townscape. London.

Davis, W. 2006. Designing Community.

Eckardt, F. 2011. Theater auf dem Theaterplatz, Kommune 1: 30-31.

Eckardt, F. 2010. Bücher für benachteiligte Leser. Stadteilbibliotheken in der gespaltenen Stadt, in Hohoff, U. und Schmiedeknecht, C. (Hg.). Ein neuer Blick auf Bibliotheken. Hildesheim: Georg Olms, 52-65.

Eckardt, F.; Karwinska, A. 2009. The Organisation of Academic Social Space. Cracow University of Economics and Bauhaus-Universität Weimar, Argumenta Oeconomica Cracoviensia 5: 27-46.

Eckardt, F. 2006a. Neighbourhood centres in Germany, Built Environment 32(1): 53-72. doi:10.2148/benv.32.1.53

Eckardt, F. 2006b. Urban myth: the symbolic sizing of Weimar, Germany, in Bell, D.; Jayne, M. (Ed.). Small Cities. Urban Experience beyond Metropolis. London: Routledge, 121-132.

Fainstein, S. S. 2010. The Just City. Cornell University Press. New York.

Feldtkeller, A. 1995. Die Zweckentfremdete Stadt. Wider die Zerstörung des öffentlichen Raums. Frankfurt am Main/ New York: Campus.
Gehl, J. 1996. Life Between Buildings. Using public space. Copenhagen.

Grunskis, T. 2009. Apie kai kurias šiuolaikines aikščiu formavimo tendencijas Lietuvoje [On Some Contemporary Square Formation Trends in Lithuania], Urbanistika ir architektūra [Town Planning and Architecture] 33(3): 135-144. doi:10.3846/1392-1630.2009.33.135-144

Hackney, R. 1990. The Good, the Bad and the Ugly. London.

Klamt, M. 2011. Öffentliche Räume, in Eckardt, F. (Ed.). Handbuch Stadtsoziologie. Wiesbaden: Verlag für Sozialwissenschaften, 560-591.

Sitte, C. 1896. Der Staedte Baunach seinen kunstlerischen Grundsatzen. Wien [City Planning According to Artistic Principles]. New York. Random House. 1965.

Stauskis, G. 2010. Architectural Development of Historical Health Care Institutions in Vilnius, Urbanistika ir architektūra [Town Planning and Architecture] 34(1): 54-63. doi:10.3846/tpa.2010.05

Stauskis, G. 2005. Optimization of Urban Model for Developing Health Care Network in Vilnius in Regional Area, Urbanistika ir architektūra [Town Planning and Architecture] 29(1): 41-46.

Stauskis, G. 2005. Methodology for Testing and Evaluating Accessibility in Public Spaces, Urbanistika ir architektūra [Town Planning and Architecture] 29(3): 147-154.

Sucker, K. 2010. Istanbul and the Heritage of the European City, Mokslas - Lietuvos ateitis [Science - Future of Lithuania] 2(3): 31-37. doi:10.3846/mla.2010.050

Vyšniūnas, A. 2008. Lukiškių aikštè - socialinio užsakymo evoliucija. Paminklas laisvès kovų dalyviams ar simbolis „Laisvë"? [Lukiškių Square - Evolution of a Social Order. A Monument to Fighters for Freedom or a Symbol of "Freedom"?], Urbanistika ir architektūra [Town Planning and Architecture] 32(4): 201-220. doi:10.3846/1392-1630.2008.32.201-220

\section{MIESTO VIEŠOSIOS ERDVĖS KAIP SOCIALINIO BENDRADARBIAVIMO VIETOS BENDRUOMENĖSE KATALIZATORIUS}

\section{G. Stauskis, F. Eckardt}

Santrauka. Viešųjų erdvių kokybės gerinimas yra svarbus miesto socialinès raidos uždavinys. Neịvertinus didelio viešųju erdvių potencialo miesto bendruomenems augti ir plètotis, dažnai viešosios erdvès miestuose yra apleistos ir neišnaudotos, kartais jos užstatomos pastatais ir išnyksta. Pasiremiant dviejų miestų - Vilniaus Lietuvoje ir Veimaro Vokietijoje - pavyzdžiais, straipsnyje analizuojami socialiniai, ekonominiai ir psichologiniai miesto viešųjų erdvių architektūrinès struktūros efektai jų poveikio įvairių mieto gyventojų grupių bendravimui aspektu. Tiriamų miestų skverų ir aikščių erdvinè kompozicija ir jų socialinis reikšmingumas kito pagal besikeičiančius istorinių laikotarpių socialinius, politinius principus: tą parodo šių viešųjų erdvių architektūrinès planinès struktūros evoliucijos tyrimas. Straipsnyje iškeliamas vietos teritorinių bendruomeniu kaip subjektu, tiesiogiai suinteresuotu greta ju gyvenamuju vietų esančių viešųjų erdvių pertvarkymu, naudojimu ir priežiūra, vaidmuo. Remdamiesi atidžiu tiriamuose Veimaro ir Vilniaus skveruose ir aikštėse vykstančiu viešojo bendravimo procesų stebėjimu, straipsnio autoriai pateikia rekomendacijas, 
kaip įvertinant miestiečių bendravimo specifiką reiktų tobulinti miestų viešųjų erdvių suplanavimą, erdvinę struktūrą, funkcionalumą ir kitus svarbius jų ịrengimo aspektus.

Reikšminiai žodžiai: urbanistinis projektavimas, kraštovaizdžio architektūra, viešoji erdvé, socialinis bendradarbiavimas, darnus mobilumas, prieinamumas.

\section{GINTARAS STAUSKIS}

Doctor of the Humanities in Architecture, Associate Professor of Vilnius Gediminas Technical University (Lithuania) conducting academic training and research activities at the Department of Urban Design, Pylimo g. 26/Traku g. 1, 01332 Vilnius, Lithuania. E-mail: Gintaras.stauskis@vgtu.lt

Involved in European Union research programmes. Member of Editorial Board of scientific journal Arhitektūra unpilsētplānošana (Riga, Latvia). Current research fields: landscape architecture and planning, "green" urban architecture and mobility, accessibility of environment, recreation and urban health. Research results have been presented in numerous national and international publications and conferences.

\section{FRANK ECKARDT}

Doctor of social science, professor, head of the Institute of European Urban Studies at the Bauhaus University, Bellvederer Alle 5, DE-99421 Weimar, Germany.

E-mail: Frank.Eckardt@uni-weimar.de

Visiting Professor at Frankfurt and Paris universities in 20002008. Heading the joint-study programme in Master of Architecture with Shanghai University, China. Focuses his research on social, economic and artistic aspects of urban environment. Takes part in different European scientific research programs and projects. The author of numerous scientific publications in Germany and abroad. 